\title{
FRENCH IMAGE OF THE INHABITANTS OF THE ILLYRIAN PROVINCES AND THE EMERGENCE OF SOUTH SLAVIC NATIONALISMS ${ }^{1}$
}

\author{
WOJCIECH SAJKOWSKI
}

\begin{abstract}
The Illyrian Provinces, a part of the 1st French Empire which existed in the years 1809-1813, are often portrayed as a political entity which anticipated various projects of the political emancipation of the South Slavs. However, the link between later pan-South-Slavic movements and the Napoleonic political activity is a matter which still remains unclear and deserves some in-depth analysis. Most often the Napoleonic impact on the evolution of the nascent South-Slavic nationalisms is viewed in the perspective of the posterior political attitudes of the Croat, Slovene or Serbian elites towards the French, and their own interpretations of the Napoleonic impact on the pan-South-Slavic movement. The proposed paper will concentrate on the opposite approach and will investigate how French perceived the South Slavs in the perspective of the nascent nationalisms, especially that French propaganda presented Napoleon as the savior of the European nations including the „Illyrian” one. But how French defined this „Illyrian” nation? This question can be answered thanks to the French strive for description of the societies inhabiting Illyrian Provinces.
\end{abstract}

Author: Wojciech Sajkowski, Adam Mickiewicz University, Faculty of History, Uniwersytetu Poznańskiego st. 7, 61-614 Poznań, Poland, wojciech.sajkowski@amu.edu.pl, ORCID iD: https://orcid.org/0000-0002-85854149

Keywords: Illyrian Provinces, nation, stereotypes, propaganda, stereotypes

Balcanica Posnaniensia. Acta et studia, XXVII, Poznań 2020, Wydawnictwo Wydziału Historii UAM, pp. 6980, ISBN 978-83-66355-54-5, ISSN 0239-4278. English text with summary in English.

doi.org/10.14746/bp.2020.27.5

The Illyrian Provinces, a part of the $1^{\text {st }}$ French Empire which existed in the years 1809-1813, are often portrayed as a political entity which anticipated various projects of the political emancipation of the South Slavs. Especially the "Illyrism", a movement that emerged among the South Slavic political elites in the fourth decade of 19th century was often regarded as somehow linked to the above mentioned short-lasting political project of Napoleon ${ }^{2}$. Illyrism became a point reference for various initia-

${ }^{1}$ ThispaperwassupportedbyagrantfromtheNationalScienceCenter, Poland(2014/13/D/HS3/03701).

2 A. Grab, Napoleon and the Transformation of Europe, New York 2003, p. 196; R. Stauber, The Illyrian Provinces, in: Napoleonic Empire and the New European Political Culture, New York 2012, p. 250 . 
tives and inspiration for politicians ${ }^{3}$. Although the postulate of the unity of the South Slavs most often was losing in favor of the nationalist perspective, the Slavic elites (especially the Slovene ones) recognized a posteriori the impact of the French on their emancipation, which is proven i.e. by a statue dedicated to Napoleon and the Illyrian Provinces, erected in Ljubljana in $1929^{4}$.

The relation between the national emancipation of the South Slavs and the French presence in Southeastern Europe is a matter which still remains unclear and deserves some in-depth analysis. Most often the Napoleonic impact on the evolution of the nascent South Slavic nationalisms is recognized in the perspective of modernization (e.g. the introduction of the Civil Code), cultural development and emancipation of the Slavic languages. It is also viewed in the context of the posterior political attitudes of the Croat, Slovene or Serbian elites towards the French, and their own interpretations of the Napoleonic impact on the pan-South-Slavic movement ${ }^{5}$. The proposed paper will concentrate on the opposite approach and will investigate how French perceived the South Slavs in the perspective of the nascent nationalisms, especially that French propaganda presented Napoleon as the savior of the European nations including the „Illyrian" one. This question is also a part of a larger problem of the strive for description of the societies inhabiting Southeastern Europe, provoked by the constant and successive political expansion of the European powers in the Balkan possessions of the Ottoman Empire in $18^{\text {th }}$ and 19th century ${ }^{6}$. It is worth to stress, that this process coincided with the emergence of the new civilizational geography of the continent (the creation of the ideas of Eastern Europe and of the Balkans) as well as the anthropological theories which served to describe ethnic groups, nations, and even races?

3 E.g. Josip Strossmayer and later Ante Trumbić: A. Bellamy, The formation of Croatian national identity, Manchester 2003, p. 45.

4 P. Troch, Nationalism and Yugoslavia: Education, Yugoslavism and the Balkans before World War II, New York 2020, p. 86-87.

5 J. Kranjc, L'administration de la justice et les lois françaises en vigueur dans les Provinces illyriennes, „Cahiers poitevins d'histoire du droit”, 2011, no. 3, p. 21-42 ; J. Dayre, Le théâtre à Raguse sous le régime français, „AIFZ”, no. 16-17, 1941, p. 95-98; F. Baras, Maršal Marmont i hrvatski jezik, „Radovi Pedagoške akademije” 1977, no. 2, p. 57-79; idem, Les Français en Dalmatie (1806-1814) = Francuzi u Dalmaciji, Split 2006 ; P. Vodopivec, Les relations entre la France et les pays Yougoslaves du dix-huitieme au vingtieme siecle:actes du [2ème] Colloque Franco-Yougoslave des historiens, qui s'est à Ljubljana les 26 et 27 septembre 1985, Lubljana 1987.

6 M. Todorova, Imaging Balkans, Oxford 2007, p. 76; W. Sajkowski, From Vinko Probojevic to the French Encyclopedia - the history of the South Slavs and the historiography of the French Enlightenment in: Colloquia Balcanica, vol. 2: Macedonia: land, region, borderland, ed. J. Sujecka, Warszawa 2013, p. 355-373.

7 J.A. Fine, When ethnicity did not matter in the Balkans: A Study of identity in pre-nationalist Croatia, Dalmatia and Slavonia in the medieval and early-modern periods, Ann Arbor 2006, p. 272; M. Todorova, Imaging Balkans, p. 50, 70; L. Wolff, Inventing Eastern Europe: the map of civilization on the mind of the Enlightenment, Stanford 1994, p. 5-16. 


\section{“ILLYRIANS" IN THE MIRROR OF THE NAPOLEONIC PROPAGANDA}

The term "Illyrian" was used by the Slavic elites for the purpose of self-identification since the end of $15^{\text {th }}$ century. It was naturally a reference to the ancient Roman province of Illyricum. This connection between the historical geography and modernity was nothing unusual in early modern historiography ${ }^{8}$, in case of this part of Europe a book Illyricum vetus et novum (Old and new Illyria) by Croatian nobleman Josip Keglević of Buzin can be mentioned ${ }^{9}$. However, the identification of the Slavs with the term "Illyria" was not always only a geographical one. In the beginning of the $17^{\text {th }}$ century Ragusan monk, Mavro Orbini presented his theory of the Slavic ethnogenesis according to which the Slavs came to Southeastern Europe from Scandinavia and they absorbed the culture of the ancient Illyrians. This idea legitimized Slavic presence in this part of Europe and became one of the early modern foundations of 19th century Illyrism ${ }^{10}$. Most probably the French had chosen the name "Illyrian Provinces" not in this context, but as a simple reference to the ancient geography and the Roman province of the Illyricum ${ }^{11}$. The geography of this part of Europe was very often regarded in the context of its Roman past, which - paradoxically - was better known than the modern geography of the European Turkey and its direct borderlands ${ }^{12}$. Whatever the reason behind the choice of such name for an new entity of the Empire was, it fitted well also the political context of the emancipation of the South Slavs.

„Télégraphe Officiel”, the official journal of the Illyrian Provinces, is the most significant document which allows to analyze the problem of the use of different names which served to address the population. The most general among them is the term „Illyrian” which was sometimes used by this journal to describe all of the inhabitants of the provinces (German, Italian, Slavic or Jewish) ${ }^{13}$ but most often it clearly referred to the Slavs and their language. The very first issue of „Télégraphe Officiel” announced the possibility of subscribing to the newspaper in French, which is the language of the government and the army, in Italian, German and Illyrian. The issue from $28^{\text {th }}$ January 1813 was reporting about "young Illyrians" which studied in the famous Prytanée military school in La Flèche, France. The list of the most outstanding students which were granted with special awards included almost only Slavic sound-

${ }^{8}$ A. Grabski, Dzieje historiografii, Poznań: Wydawnictwo Poznańskie 2006, p. 267, 203, 241.

9 This work was in fact a compilation of fragments of a work Historia Bizantina written by French historiographer and Byzantynist, Charles du Cange, with the rather brief addition describing the history of the South Slavs in medevial and early modern times - W. Sajkowski, From Vinko Probojević..., p. 341.

10 Z. Blažević, Ilirizam prije ilirizma, Zagreb 2008, p. 157-191.

11 R. Stauber, The Illyrian Provinces..., p. 45.

12 It was only in the second half of the 18th century when the French started to describe the east coast of Adriatic in more detailed way: W. Sajkowski, Obraz ludów bałkańskiego wybrzeża Adriatyku we Francji epoki Oświecenia, Poznań 2013, p. 27-43.

13 „Télégraphe Officiel”, 02.01.1811. 
ing names ${ }^{14}$. Furthermore, „Télégraphe Officiel” in the earlier issue from $29^{\text {th }}$ August 1812 mentioned "young Illyrians", reporting that they could now "study the language of their fatherland" in lycée (high school) of Ljubljana ${ }^{15}$, which could suggest, that they belonged to one nation which spoke one language.

The mention about the Illyrians studying in La Flèche inscribes itself in the scheme of the French propaganda which wanted to prove, that Napoleon cares about his new subjects. Even more direct example of such message was presented by „Télégraphe Officiel" from the $24^{\text {th }}$ august 1811 which mentioned Croat students who were sent to study in famous school of arts and crafts in Chalons-sur-Marne ${ }^{16}$. Journal mentioned, that "Illyrians will praise the magnanimity of the Emperor", who by paying the scholarships "wished to involve the most remote peoples of his vast states in the benefit of an institution of which France seems to feel alone the salutary influences"17. This citation presented the Emperor as a ruler who cares about the economy of the "Illyrian nation”, however in most cases he was simply presented as it's ,liberator”, which was more usual propaganda scheme legitimizing his power as coming from the people ${ }^{18}$.

Overall, the use of the term „Illyrians” by „Télégraphe Officiel” was superficial, and meant rather ,the Slavic people" than the nation. Moreover, Napoleon did not promote (and most probably he also did not have) any particular, nor coherent idea of a nation ${ }^{19}$. He used the concepts developed during the French Revolution in a very instrumental way, as one of the means to legitimize his power ${ }^{20}$. E.g. the revolutionary ideal of the „citizen soldier” (le soldat-citoyen) ${ }^{21}$ which delivered new justification for the military mobilization, evoking the patriotism and obligation towards the society instead of relying just on a loyalty towards the sovereign, was very useful for propaganda, which merged it with other elements ${ }^{22}$.

14 Journal mentions Paul François Krusich of Zara, Mathieu Frédéric Orescovich of Perusić, Michel Jovetich Jesenice, etc. (...) les premières efforts des jeunes Illyriens dans l'étude de la nouvelle langue de leur patrie; ,Télégraphe Officiel”, 28.01.1813.

15 Ibidem, 29.08.1812.

16 J. Pannabecker, School for Industry: L'Ecole d'Arts et Métiers of Châlons-sur-Marne under Napoléon and the Restoration, ,Technology and Culture” 2002, vol. 43, no. 2, pp. 254-290.

17 “,Télégraphe Officiel”, 24.08.1811.

18 „Télégraphe Officiel”, 29.06.1811.

19 S. Englund, Napoleon: A Political life, New York 2004, s. 199.

20 After the fall of the Illyrian Provinces the Austrians preserved the name „Illyria”, and created the Kingdom of Illyria which existed as a part of the Habsburg Empire from 1816 to 1849. In this case the use of the adjective „Illyrian”, as well as recognition of the different Slavic ethnicities was not intended to stimulate the national emancipation, but it was an instrumental practice for the purpose of propaganda; R. Stauber, The Illyrian Provinces..., p. 45.

21 In fact the origins of this military ideal are even pre-revolutionnary; A. Guinier, De l'autorité paternelle au despotisme légal: pour une réévaluation des origines de l'idéal du soldat-citoyen dans la France des Lumières „La Revue d'histoire moderne \& contemporaine” 2014, no 61-2, p. 150-175.

22 A. Forrest, L'armée de l'an II : la levée en masse et la création d'un mythe républicain, „Annales historiques de la Révolution française" 2004, no. 335, p. 111-120. 
Interestingly, even if „Télégraphe Officiel” sometimes used this aspect of „popular" legitimization of power, the vast majority of mentions presented the inhabitants of the Illyrian Provinces not as the citizens, but as a subjects devoted to their ruler ${ }^{23}$. Hence, even if „Télégraphe Officiel” used the expression „Dalmatian citizens” (les citoyens Dalmates ${ }^{24}$ ), the image of the enthusiastic response for the appeals of mobilization had more in common with more traditional and paternalistic model of the loyalty towards the sovereign than with the image of the citizens willing to protect the republic. „Télégraphe Officiel” from 20th of February 1811 explicitly underlined, that the reason behind the fast mobilization of the troops lies in the dedication (...) for the person of His Majesty ${ }^{25}$. Issue of the newspaper from the 13th of April of the same year informed about the formation of the new regiment of the light infantry from the newly enlisted recruits. According to journal, the surprising promptness with which this regiment was formed is a new proof of the influence exercised over all minds by the genius of the hero of France; it is also the proof of the love which the people of Illyria bear to their sovereign ${ }^{26}$.

\section{SLAVDOM AS ONE ENTITY IN THE OBSERVATIONS OF THE FRENCH ADMINISTRATORS OF THE ILLYRIAN PROVINCES}

The testimonies left by the French administrators of the Illyrian Provinces are other important documents which allow to understand the French perception of the South Slavdom. Those testimonies couldn't influence the development of the Slavic nationalism, as they were made for internal purposes of the French administration, and most often remained manuscripts. Yet, they shed some light on how French perceived their Slavic subjects.

In most cases, the French administrators of the Illyrian Provinces were not determining the ethnicity of the inhabitants, and used names which were simple reference to the city or province which given group was inhabiting (Ragusans, people of Istria, people of Carniola). Such mentions do not give any specific information concerning confession or language. Hence, the term "people of Carniola" could be used to describe both Slavic, Italian and German population of the province. This practice is apparent e.g. in the correspondence of the intendant of Carniola and Carinthia, FrançoisMarie Fargues, who used a very general term „the people” (le peuple), ,inhabitants of

23 W. Sajkowski, French image of the peoples inhabiting Illyrian Provinces, Warsaw-Bellerive-surAllier 2018, p. 40-66.

24 „Télégraphe Officiel”, 01.04.1811.

25 Ibidem, 20.02.1811.

${ }^{26}$ La promptitude surprenante avec laquelle s'est formé ce Régiment est une nouvelle preuve de l'influence qu'exerce sur tous les esprits, le génie du Héros de la France; c'en est aussi une de l'amour que les peuples de l'Illyrie portent à leur souverain; ibidem, 13.04.1811. 
Carniola”, or even „inhabitants of the provinces”27. What strikes most, even in case of the German population of Kočevje area (Gottschee) which was rebelling against the French, and collaborated with Austrians, Fargues did not emphasized their specific ethnic status, which obviously was one of the important reasons behind those unrests.

„The Dalmatians" (les Dalmates) is another example of a name which describes simply a population inhabiting certain geographic region. The same concerned the Croats (les Croates), a name which often was used to describe all inhabitants of the Croatian Military frontier (including the Serbs) ${ }^{28}$. This geographical criterion of understanding of the term les Dalmates, les Carniens, or les Croates fits also the French perception of the Slavs, which developed in 18th century. Already in the year 1734 French historian J.G. Jolli stated that Slavs are a homogenic nation, which has many names, according to the region which they populate"29. J.G. Jolli published his work in 1734, three decades later, in 1765 French historian and diplomat ClaudeCharles de Peyssonnel ${ }^{30}$ developed this theory on the unity of the Slavs, which - according to him - were one of many barbaric tribes which invaded Europe in late Antiquity and Middle Ages.

At the beginning of the 19th century the French officers and administrators of the Illyrian Provinces seemed to share this presumption on the Slavic unity. In their opinion, the differences between particular groups of the Slavs inhabiting the Illyrian Provinces were caused by the complicated political history of the lands which formed this entity of the Napoleonic Empire. The best example are the Dalmatian lands known under the name of Nuovo e Nuovissimo Aquisto, which were formerly under the Turkish control. This period of Ottoman reign was considered as the crucial factor which influenced the character of the Slavic population of Dalmatian interior known under the name of Morlachs. General Molitor stated, that this population conserved social structure from the Ottoman times, as they were led by arambassas i.e. chiefs of the nation which conserve the titles and the same character with which their ancestors served under the Turkish domination (... $)^{31}$. Another French officer, Mathieu

27 F-M. Fargues, Nastajanje Napoleonove Kranjske: korespondenca Françoisa-Marie Farguesa, francoskega intendanta za Kranjsko in Gorenjsko, 1809-1810 = Avenement de la Carniole Napoléonienne, eds. J. Šumrada, A. Kopitar Ljubljana 2004, p. 137, 330, 162.

28 W. Sajkowski, French image..., p. 40-66.

29 (...) cette Nation se partagea en. autant de noms différents qu'elle occupa de Provinces. Ceux qui s'établirent deçà \& delà le Danube prirent le nom de Serviens, Bulgares, Bosniens, Carniens, Rasciens, Dalmates, Esclavons, Illyriens, \& Istriens ; J.G. Jolli, Histoire Des Rois Et Du Royaume De Pologne, Et Du Grand Duche De Lituanie, La Haye 1734, vol. 1, p. 4-5.

$30 \mathrm{C}-\mathrm{Ch}$. De Peyssonnel, Observations historiques et géographiques sur les peuples barbares qui ont habité les bords du Danube et du Pont-Euxin ; suivies d'un Voyage fait à Magnésie, à Thyatire, à Sardes, \&c. Contenant une Relation de ce qu'il y a de plus curieux en Monuments Antiques, Inscriptions, Médailles, dont plusieurs n'étaient pas encore connus; \& précédées d'une Dissertation sur l'origine de la Langue Sclavone prétendue Illyrique, Paris 1765.

31 (...) des chefs de la nation qui conservent encore le titre et le même caractère avec lequel leurs ancêtres servaient sous la domination des Turcs (...); G. Molitor, Rapport au général Molitor, (23 pages 
Dumas, prepared more general report on Dalmatia in which he also considered the inhabitants of the formerly Turkish lands of the province as the separate group ${ }^{32}$. Another testimony, made by colonel Sorbier, divided the population of Dalmatia not into two, but three parts, according to the differences in their "moral history". French officer also emphasized the difference between population of littoral Dalmatia, which he considered as Italian (and civilized) and Morlachs which, were directly identified with barbarians, more precisely Scythians (similar observation was made by general d'Anthouard ${ }^{33}$ ). Division presented by general Molitor included also third group, Greek (i. e. Orthodox) population of Dalmatia, which was, according to him, "devoted to the Emperor of Russia to which they are dedicated as to the head of religion.". Obviously Molitor's report was somehow very inconsequent, as each group was distinguished according to different criterion: linguistic (littoral Dalmatians), ethnogenetic (,Scythian” Morlachs) and religious („Greeks”).

In some of the reports the officers and officials used the term ,nation" to describe various of those groups, e.g. the Morlachs, or littoral, Italianized Dalmatians. However it seems that they used this term rather loosely, considering a majority of them as Slavs, or at least descendants of the barbarians. Such perspective is clearly visible in the reflections of the first Governor-General of the Illyrian Provinces, marshal Marmont, who considered the Croats (the inhabitants of the Croatian Military Frontier) as more civilized than Dalmatian Morlachs. This second group was presented in a pejorative way, as the barbarians whose lack of self-discipline could be tamed only by the military regime, similar to the one functioning in the Military Croatia ${ }^{34}$. Years later, he repeated this statement in his memoirs, once more emphasizing that Morlachs were barbarians, which "without organisation, will hardly do any civilizational progress" "35. The sad and poor land, as he named littoral Dalmatia was according to him inhabited by the people valiant and capable of enthusiasm; ignorant, simply confident, able to devotion to their leaders, but, like all barbarians, they do not un-

et 2 tableaux, dont l'un daté du 28 février), Service historique de la Défense, Département de l'armée de terre $1 \mathrm{M} 1617$, p. 2.

32 M. Dumas, Rapport de général Mathieu Dumas (2 cahiers, 5 et 37 pages, avec un état des revenus du royaume de Dalmatie), Service historique de la Défense, Département de l'armée de terre 1M 1617, p. 23.

33 Ch-N. d'Anthouard, Description topographique et militaire de la Dalmatie, par le général de brigade d'Anthouard, aide de camp du prince Eugène, Milan, 10 juin 1806), Service historique de la Défense, Département de l'armée de terre 1M 1590-1591, p. 11.

34 F-L. Viesse de Marmont, Croatie Croatie militaire : mémoire sur les régiments frontières, http:// www.napoleonica.org/gerando/GER02402.html [access: 10.12.2015].

35 (...) des barbares, sans organisation, ne feront que difficilement des progrès dans la civilisation. L'exemple qu'offrent les Morlaques, Dalmates, comparés aux Croates, leurs voisins, qui, par suite de leur organisation, sont devenus bien supérieurs à eux, confirme ce précepte, F-L. Viesse de Marmont, Mémoires du Duc de Raguse: de 1792 a 1832: imprimés sur le manuscrit original de l'auteur, Paris, vol. 3., p. 27. 
derstand abstractions $(\ldots)^{36}$. He also mentioned that those barbarians (i.e. Morlachs) were "descendants of Ancient Slavs, which conquered this country" ${ }^{37}$. It is possible to presume, that Marmont would not label them as a ,nation” similarly to French or Germans, since he claimed, that their ancient barbarism remains an immanent feature of the Morlach character.

Also Charles Nodier, chief editor of „Télégraphe Officiel” (and a famous romantic man of letters) or Marcel de Serres (French naturalist, but also an agent sent by French government to describe Austria), used the term of "nation” to describe the entirety of the European Slavs. It meant, that the Slavic population of Illyria could be regarded only as a branch of the „Slavic nation”. This is clearly visible in Marcel de Serres' Voyage en Autriche, where French or Italians are presented as one nation, while Windes (i.e. Slovenes) or Croats are part of a larger branch of ,oriental Slavs” along with Russians or Samoyeds (sic!). The „Illyrian Slavs” also appear in this enumeration, listed as a part of this oriental branch yet this name was treated as synonymous with „Rascians”, i.e., Serbs ${ }^{38}$. This shows, that the term "Illyrians" could be also used to describe only one of the South Slavic ethnicities, and not all of them.

\section{THE BEGINNINGS OF THE DISTINCTION BETWEEN DIFFERENT SLAVIC LANGUAGES AND NATIONS}

Even if French still perceived the Slavs as one entity, the episode of their rule over the Illyrian Provinces allowed them to see more and more differences between various Slavic groups. The first observation concerned the differences within the language of the South Slavs. The Illyrian language (la langue illyrique or la langue illyrien), as it was labeled, was according to the French (e.g. Charles Nodier) crucial element of the Slavic culture and identity ${ }^{39}$. In fact there were many Slavic languages used in the Illyrian Provinces, so it is important to ask whether French could discern them.

The analysis of the various French testimonies proves, that French were conscious that the languages used by the South Slavs are not homogenous. E.g. according to Conrad Malte-Brun's Annales des voyages de la géographie de l'histoire, the Slavs of Styria and Carniola were speaking their own dialect ${ }^{40}$. The distinctive nature of the language used by the Carniolan Slavs was observed also by Marcel de

36 Mais ce pays, si triste et si pauvre, est habité par une population belle, valeureuse et susceptible d'enthousiasme; ignorante, simple confiante, capable de dévouement pour ses chefs: mais, comme tous les Barbares, elle ne comprend pas les abstractions; pour la remuer, il faut frapper ses sens et la soumettre une action matérielle; ibidem.

37 L'intérieur est très-misérable, uniquement habité par les descendants des anciens Slaves qui l'ont conquise; ibidem, p. 26.

38 M. de Serres, Voyage en Autriche, vol. 4, Paris 1814, p. 378.

39 Ch. Nodier, Langue Illyrienne, „Télégraphe Officiel”, 30.05.1813, p. 43.

40 C. Malte-Brun, Annales des voyages de la géographie de l'histoire, vol. 2, Paris 1809, p. 260. 
Serres in his Voyage en Autriche: It is above all in the mouth of a Carniolan that the Slavic seems to have harmony and seems capable of to absorb these varied intonations which make the charm of the Italian language. Nothing is so hard, on the contrary, as the guttural accent of the Slavs of Bohemia and Styria, especially those who inhabit the arid and mountainous regions of these provinces ${ }^{41}$. This mention proves that French noticed the specific character od Slovenian language, yet they considered it as a dialect, a variety of Slavic, which nature was shaped by Italophone and Germanophone influence.

The contact with the Slavic elites of the Illyrian Provinces forced French to reconsider their view on different "dialects" of the "Illyrian language". Valentin Vodnik, at the time the director of the secondary school (lycée) in Lubljana published in „Télégraphe Officiel” (issue from $31^{\text {st }}$ July 1811) a poem in Slovenian, entitled Illyria oshivlena-Illyria rediviva (Illyria resurrected). It was recommended for readers who know Illyrian langue the best pieces of poetry which were written in the Carniolan dialect $t^{42}$. „Télégraphe Officiel”, similarly to the abovementioned publication of Conrad Malte-Brun considered the language of the Slavs of Carniola only "a dialect", yet it was presented as a dialect proper for poetry, hence not a language of barbarians unworthy of art and science, as French diplomat and historiographer Claude-Charles de Peyssonnel was writing in 1765 in his work about the origin of the Slavic peoples ${ }^{43}$. Also „Télégraphe Officiel” mentioned about the planned publication of GermanoSlovene-Latin dictionary (Deutsch-Slowenisch-Lateinisches Wörterbuch/ Slovar Nemshko-Slovensko-Latinski) written also by Valentin Vodnik. It was most possibly Charles Nodier himself, at the time the main director of the newspaper, ${ }^{44}$ who reviewed the manuscript of the dictionary enthusiastically, and emphasized that Slovene (mentioned only in the title of the work) is a well-circumscribed dialect, which is properly called Carnique, and which is spoken in Carniola, in Carinthia; in Trieste and Gorice, without any modification. Relying on Vodnik's opinion Nodier stated that this speak bears all the characteristics of a great antiquity and indigenous purity, to such an extent that it is regarded by some scholars as the type of all other [Slavic dialects $]^{45}$. This characteristic of Slovene still used the term ,dialect” however it also

41 Cette même langue est, au contraire, plus douce et plus mélodieuse chez les Slawes qui habitent des plaines riantes et fertiles : c'est surtout dans la bouche d'une Carniolienne que l'esclavon parait avoir de l'harmonie, et semble susceptible de recevoir ces intonations variées qui font le charme de la langue italienne. Rien n'est si dur, au contraire, que l'accent guttural des Esclavons de la Bohême et de la Styrie, surtout de ceux qui habitent les contrées arides et montagneuses de ces provinces; M. de Serres, Voyage en Autriche..., vol. 4, p. 324.

${ }^{42}$ Le petit recueil de poésies carnioliennes publié par M. l'Abbé Vodnik, Directeur du Gymnase de Laybach, content au jugement de tous les gens de goût qui possèdent la langue illyrique, les meilleurs morceaux de poésie qui aient été composés dans le dialecte carniolien, „Télégraphe Officiel”, 31.07.1811.

43 C-Ch. De Peyssonnel, Observations historiques et géographiques..., p. X.

44 R. Maixner, Charles Nodier en Illyrie, ,Revue des études slaves” 1924, no. 3., p. 254-255.

45 M. le professeur, Valentin Vodnik a donné la marque d'un excellent goût en nous annonçant qu'il restreignait le choix des mots qui doivent entrer dans son dictionnaire a un dialecte bien circonscrit, cela 
described is as ,pure” and ,indigenous”, hence it ennobled it, equating with other European languages.

More accurate knowledge on the languages used by South Slavs went hand in hand with change of the association of certain ethnonyms. As it was already mentioned, French sometimes used the name "nation" to describe various groups of their Illyrian subjects, without further specification of the purpose of using such term, especially in the context of presumed homogeneity of the Slavs. However in few cases, the observers used this term to describe a community which had its social structure comparable to the structure of other European societies labeled as „nations", e.g. French or Italians. In one of his letters addressed to Napoleon general Lauriston described Croats living in the Civil Croatia as something more than just a horde of barbarians, but rather as a modern society which was divided into several classes: nobles and clergy, bourgeoisie, free inhabitants and serfs ${ }^{46}$. Even more detailed observation were made by captain Leclerc in his report on the Croatian society entitled Rapport sur la marche du gouvernement et l'esprit des peuples en Croatie, dated on $27^{\text {th }}$ February $1810^{47}$.

\section{CONCLUSIONS}

The French rule over Illyrian Provinces certainly contributed to development of the Slavic nationalism, mainly because of the various activities in the field of education and culture which were already vastly described in scientific literature. However the analysis outlined in this paper shows, that this practice of governance did not went hand in hand with some clear idea of any of the South Slavic nations, or even with some more general concept of the „Illyrian” one. This phenomena partially stemmed from the fact of the instrumentalization of the idea of a nation by Napoleon, but most importantly it reflected French knowledge on the South Slavs, which was rooted in the literature of Western European Enlightenment. In 18 th and early 19th century the Slavs were often represented as one entity, which inner differentiation was of secondary importance and was a consequence of adaptation to the different natural and cul-

\footnotetext{
que l'on appelle proprement le Carnique et qui se parle en Carniole, en Carinthie; à Trieste et à Gorice, sans aucune modification. Il en résultera que nous saurons parfaitement à quoi nous en tenir sur une très grande division de la langue slave, et sur celle, par parenthèse, que les lexicographes ont le moins considérée jusqu'ici, quoiqu'elle porte tous les caractères d'une grande antiquité et d'une pureté autochtone, à tel point qu'elle est regardée par quelques savants comme le type de toutes les autres; „Télégraphe Officiel”, 27.06.1813.

46 J. Law de Lauriston, Laybach le $159 b r e 1810$ A Sa Majesté, Archives Nationales, Site Paris, Site Pierrefitte-sur-Seine 201AP.

47 Leclerc, Rapport sur la marche du gouvernement et l'esprit des peuples en Croatie, par le colonel Leclerc, aide de camp du ministre de la guerre, Paris, 27 février 1810, Service historique de la Défense, Département de l'armée de terre 1 M 1598, dos. 13.
} 
tural conditions (e.g. functioning on mountainous or lowland areas, the influence of German or Italian culture), and that is why the French documents were describing the Illyrian population so freely and inconsequently. This perspective was rather pejorative as it led to simplifications which became a part of the stereotype of the homogenous character of the Eastern Europe and the Balkans.

However the presence of the French in the space inhabited by the South Slavs, even if it was rather short, distorted this idea of homogenic Slavdom. The French discovery of the Slovene language is one of the most striking examples of this phenomena. As Ljubljana was the capital of the Illyrian Provinces the direct contacts of the French with the local Slovene elites became something natural, and became one of the factors which deepened French knowledge on the local population.

\section{BIBLIOGRAPHY}

Anthouard Charles-Nicolas de, Description topographique et militaire de la Dalmatie, par le général de brigade d'Anthouard, aide de camp du prince Eugène, Milan, 10 juin 1806,), Service historique de la Défense, Département de l'armée de terre 1 M 1590-1591.

Baras Frano, Maršal Marmont i hrvatski jezik, „Radovi Pedagoške akademije” 1977, no. 2, p. 57-79.

Baras Frano, Les Français en Dalmatie $(1806-1814)=$ Francuzi u Dalmaciji, Split 2006.

Bellamy Alex, The formation of Croatian national identity, Manchester 2003.

Blažević Zrinka, Ilirizam prije ilirizma, Zagreb 2008.

Dayre Jean, Le théâtre à Raguse sous le régime français, „AIFZ” 1941, no. 16-17, p. 95-98.

Dumas Mathieu, Rapport de général Mathieu Dumas (2 cahiers, 5 et 37 pages, avec un état des revenus du royaume de Dalmatie), Service historique de la Défense, Département de l'armée de terre 1M 1617.

Englund Steven, Napoleon: A Political life, New York 2004.

Fine John Antwerp, When ethnicity did not matter in the Balkans: a study of identity in pre-nationalist Croatia, Dalmatia and Slavonia in the medieval and early-modern periods, Ann Arbor 2006.

Forrest Alain, L'armée de l'an II : la levée en masse et la création d'un mythe républicain, „Annales historiques de la Révolution française" 2004, no. 335, p. 111-130.

Grab Alexander, Napoleon and the Transformation of Europe, New York 2003.

Grabski Aleksander, Dzieje historiografii, Poznań 2006.

Krajnc Janez, L'administration de la justice et les lois françaises en vigueur dans les Provinces illyriennes, „Cahiers poitevins d'histoire du droit” 2011, no. 3, p. 21-42.

Gunier Arnaud, De l'autorité paternelle au despotisme légal: pour une réévaluation des origines de l'idéal du soldat-citoyen dans la France des Lumières „La Revue d'histoire moderne \& contemporaine" 2014, no 61-62, p. 150-175.

Jolli J.G., Histoire des rois et du royaume de Pologne, et du grand duche de Lituanie, La Haye 1734.

Lauriston Jacques Law de, Laybach le 15 9bre 1810 A Sa Majesté, Archives Nationales, Site Paris, Site Pierrefitte-sur-Seine 201AP.

Leclerc, Rapport sur la marche du gouvernement et l'esprit des peuples en Croatie, par le colonel Leclerc, aide de camp du ministre de la guerre, Paris, 27 février 1810, Service historique de la Défense, Département de l'armée de terre 1 M 1598, dos. 13.

Malte-Brun Conrad, Annales des voyages de la géographie de l'histoire, Paris 1809.

Maixner Rudolf, Charles Nodier en Illyrie, „Revue des études slaves” 1924, no. 3., p. 252-263.

Marmont Auguste Frédéric Louis Viesse de, Croatie Croatie militaire : mémoire sur les régiments frontières, http://www.napoleonica.org/gerando/GER02402.html [access: 10.12.2015]. 
Marmont Auguste Frédéric Louis Viesse de, Mémoires du Duc de Raguse: de 1792 a 1832: imprimés sur le manuscrit original de l'auteur, Paris, vol. 3.

Molitor Gabriel, Rapport au général Molitor, (23 pages et 2 tableaux, dont l'un daté du 28 février), Service historique de la Défense, Département de l'armée de terre 1M 1617.

Pannabecker John, School for Industry: L'Ecole d'Arts et Métiers of Châlons-sur-Marne under Napoléon and the Restoration, „Technology and Culture” 2002, vol. 43, no. 2, p. 254-290.

Peyssonnel Claude-Charles de, Observations historiques et géographiques sur les peuples barbares qui ont habité les bords du Danube et du Pont-Euxin; suivies d'un Voyage fait à Magnésie, à Thyatire, à Sardes, \&c. Contenant une Relation de ce qu'il y a de plus curieux en Monuments Antiques, Inscriptions, Médailles, dont plusieurs n'étaient pas encore connus; \& précédées d'une Dissertation sur l'origine de la Langue Sclavone prétendue Illyrique, Paris: Tilliard 1765.

Serres Marcel de, Voyage en Autriche, Paris: Bertrand 1814, vol. 4.

Stauber Reinhard, The Illyrian Provinces, in: Napoleonic Empire and the New European Political Culture, New York 2012, p. 241-253.

Sajkowski Wojciech, From Vinko Probojevic to the French Encyclopedia - the history of the South Slavs and the historiography of the French Enlightenment, in: Colloquia Balcanica, vol. 2: Macedonia: land, region, borderland, ed. J. Sujecka, Warszawa 2013, p. 355-373.

Sajkowski Wojciech, French image of the peoples inhabiting Illyrian Provinces, Warsaw-Bellerive-surAllier 2018.

Sajkowski Wojciech, Obraz ludów bałkańskiego wybrzeża Adriatyku we Francji epoki Oświecenia, Poznań 2013.

„Télégraphe Officiel”, 1810-1813, in: Digitalna knjižnica Slovenije, www.dLib.si, [access: 01.04.201502.05.2018].

Todorova Maria, Imaging Balkans, Oxford 2007.

Troch Pieter, Nationalism and Yugoslavia: education, Yugoslavism and the Balkans before World War II, New York 2020.

Wolf Larry, Inventing Eastern Europe: the map of civilization on the mind of the Enlightenment, Stanford 1994.

Vodopivec Peter, Les relations entre la France et les pays Yougoslaves du dix-huitieme au vingtieme siecle:actes du [2ème] Colloque Franco-Yougoslave des historiens, qui s'est à Ljubljana les 26 et 27 septembre 1985, Ljubljana 1987. 